\title{
ANALGESIC ACTIVITY OF CRUDE AQUEOUS EXTRACT OF THE ROOT BARK OF ZANTHOXYLUM XANTHOXYLOIDES
}

\author{
A.B.A. PREMPEH ${ }^{1}$ and J. MENSAH-ATTIPOE ${ }^{2}$ \\ ${ }^{1}$ Department of Pharmacology, University of Ghana Medical School, College of Health Sciences, P. O. Box \\ 4236 Accra Ghana ${ }^{2}$ Department of Pharmacology, School of Medical and Health Sciences, \\ University for Development Studies, P. O. Box 1350 Tamale, Ghana
}

\author{
Author for correspondence: Dr A. B. A Prempeh, E-mail: abaprempeh@chs.edu.gh \\ Conflict of Interest: None declared
}

\section{SUMMARY}

Objective: The analgesic activity of crude aqueous extract of the root bark of Zanthoxylum xanthozyloides was studied in mice and rats with the view to verifying the claim in folklore medicine that the extract has analgesic activity.

Method: The extract was obtained by Soxhlet extraction and rotatory evaporation, followed by freezedrying. Groups of rats and mice were, respectively, assigned randomly to treatment groups. The animals received three different treatments orally: $0.9 \%$ saline (control), the extract $(400 \mathrm{mg} / \mathrm{kg}$ and $800 \mathrm{mg} / \mathrm{kg}$ for mice; $1000 \mathrm{mg} / \mathrm{kg}$ and $2000 \mathrm{mg} / \mathrm{kg}$ for rats) and indomethacin $(5 \mathrm{mg} / \mathrm{kg}$ and $10 \mathrm{mg} / \mathrm{kg}$ for mice; $10 \mathrm{mg} / \mathrm{kg}$ and $20 \mathrm{mg} / \mathrm{kg}$ for rats). Each group of animals was rotated through the entire treatment groups such that each animal served as control as well as received all the treatments. The hot-plate and paw-pressure methods were used to study pain perception in the treated animals. Analysis of variance was used as the statistical test.

Results: In both methods, the extract and indomethacin caused dose-dependent elevation in pain threshold. At the peak of activity, $400 \mathrm{mg} / \mathrm{kg}$ and $800 \mathrm{mg} / \mathrm{kg}$ extract caused $74 \%$ and $95 \%$ increase in the reaction time respectively whilst $5 \mathrm{mg} / \mathrm{kg}$ and $10 \mathrm{mg} / \mathrm{kg}$ indomethacin gave $97 \%$ and $116 \%$ increment respectively. Similarly, $1000 \mathrm{mg} / \mathrm{kg}$ and $2000 \mathrm{mg} / \mathrm{kg}$ extract caused $65 \%$ and $84 \%$ increase in pain threshold whilst $10 \mathrm{mg} / \mathrm{kg}$ and $20 \mathrm{mg} / \mathrm{kg}$ indomethacin caused $95 \%$ and $113 \%$ increment respectively.

Conclusion: It was concluded that the extract induced analgesia, probably, by inhibiting prostaglandin production, just as did indomethacin.

Key Words: root bark extract, Zanthoxylum xanthoxyloides, pain threshold, analgesia.

\section{INTRODUCTION}

Crude aqueous extract of the root bark of Z. xanthoxyloides is used in Ghana and Nigeria for its antirheumatic activity, anti-sickling, anti-microbial, antiinflammatory and analgesic properties, for example, in the treatment of painful conditions in childbirth and toothache. The extract is also used as an antiseptic. ${ }^{1}$ Isolated and purified alkaloids of the root bark, namely, 3, 4-dihydro-2-diurethyl-2H-1- benzopyran-6-butyric acid (DBA), a benzopyran butyric acid derivative of zanthoxylol and piperonyl-4-acrylic isobutylamide (fagaramide) $)^{2}$, have been identified to have antiprostaglandin synthetase activity as well as antiinflammatory activity, using plethysmometry method. The former activity, which is responsible for inhibition of prostaglandin synthesis, contributes to the antiinflammatory activity of fagaramide.

The plethysmometry method ${ }^{2}$ established the antiinflammatory activity but not the analgesic activity of fagaramide. Since the extract is used mainly as analgesic agent, investigation into the effect of the extract on pain threshold became particularly relevant. This would provide scientific basis for its use in folklore medicine and, also, for the search of cheap and safe herbal medication for relieving pain. The conventional NSAIDs have been associated with serious adverse effects whilst the relatively safe COX-II selective inhibitors are expensive and not available to most of the Ghanaian populace.

For the purpose of studying the analgesic activity of the extract, experimental models for measuring pain threshold, namely, hot-plate ${ }^{3}$ and rat paw-pressure ${ }^{4}$ methods were chosen. All the doses of the extract used were within the dose range (on the dose axis) corresponding to the linear portion of the log dose-response curve.

\section{MATERIALS AND METHODS}

\section{Collection and extraction of the root bark}

The roots of $Z$. xanthoxyloides (identified and confirmed in the Department of Botany, University of Ghana, Legon) were collected from a forest at Akatsi, Volta Region, in the month of August and solar-dried for 1 day. The root barks were removed, washed, and dried in hot oven $\left(55^{\mathrm{O}} \mathrm{C}\right)$ for five days. The dried root barks were pulverized to powder. Aliquot of the pow- 
der, $300 \mathrm{~g}$, was extracted in water, 3L, in Soxhlet apparatus. ${ }^{5}$ The extraction was allowed to continue until a point where no more brown colouration was imparted to the water. This was used as an index for completion of extraction. The clear brown extract was concentrated 10 -fold in a rotatory evaporator (Bibby Sterilin Rotatory evaporator RE - 100). The viscous brown fluid was freeze-dried in Edward Modulyo freeze-drier (Edwards High Vacuum). The freeze-dried powder was stored at $-18^{\circ} \mathrm{C}$ until when needed. Reconstituted freeze-dried powder in $0.9 \%$ saline is referred to as "the extract" in this text.

\section{Hot-plate method}

Preliminary study of the phenomenon of adaptation of nociceptors to repetitive application of stimulus was undertaken to determine the onset and time span of the adaptation. This knowledge was required to administer the extract and measure the pain threshold at a time when there was no adaptation, i.e., to determine the appropriate dosing interval. The adaptation was studied by examining the relationship between responses to thermal pain and varying frequency of the stimulus application. The study showed that the onset of adaptation was directly related to the frequency of stimulus application and that no adaptation occurred when the stimulus was applied at 3-day intervals. Consequently, the effect of the extract on pain threshold was studied at 3-day intervals.

Twenty five Balb/C mice (25-35g) of both sexes (13 males and 12 females) were randomly assigned to 5 treatment groups of 5 mice each. One group received $0.9 \%$ saline on weight basis (control); two groups were given two dose levels of indomethacin, $5 \mathrm{mg} / \mathrm{kg}$ and $10 \mathrm{mg} / \mathrm{kg}$ respectively; and the remaining two groups given the extract at two dose levels, $400 \mathrm{mg} / \mathrm{kg}$ and $800 \mathrm{mg} / \mathrm{kg}$ respectively. Each mouse was placed on a hotplate $\left(55^{\circ} \mathrm{C}\right)$ and the time lapse for the mouse to respond to the thermal pain (reaction time) was noted. Rubbing of palms or jumping was used as endpoint. The reaction time was determined at $0,1,2,3$, and $5 \mathrm{hr}$ after each treatment. Each group of mice was rotated through the entire five treatment groups (randomized complete block design) at 3-day intervals, and reaction time determined in each rotation. Thus each mouse served as a control as well as received the other four treatments, i.e., the mice were self-matched. The mice were rested for one week after every two rotations.

The mean reaction time for each treated group was determined and compared with that obtained for each group before treatment. Percentage increase in reaction time, $\mathrm{I} \%$, was derived, using the formula ${ }^{6} \mathrm{I} \%$
$=\{(\mathrm{It}-\mathrm{Io}) / \mathrm{Io}\} \times 100$ Where $\quad \mathrm{It}=$ reaction time at time, $\mathrm{t}$, and Io $=$ reaction time at time zero $(0)$

A graph of percentage increase in reaction time was plotted against time. Analysis of variance (MegaStat, excel) was used to compare the means of the reaction time of the different groups. Post hoc analysis (aftertest ANOVA) was employed to compare the means of paired observations. Differences at $p<0.05$ were considered significant.

\section{Paw-pressure method}

Preliminary study of the time course of the analgesic activity of carrageenin in the rat paw was undertaken to determine time to peak analgesic activity which was used as an index of the time lapse to attain peak concentration of the agent at the site of action. This was used to determine the dosing interval between carrageenin and the extract or indomethacin as well as the duration of each study. After treatment with $0.1 \mathrm{ml}$ of $1 \%(\mathrm{w} / \mathrm{v})$ carrageenin in $0.9 \%$ saline, reduction in pain threshold was detectable after $1 \mathrm{hr}$, reached a nadir at 3 $\mathrm{hr}$, and thereafter remained constant until $7 \mathrm{hr}$ when a gradual increase in pain threshold became manifest. The effect of the extract on pain threshold was, therefore, studied by administering the extract $2 \mathrm{hr}$ after treatment with carrageenin, and each study was limited to $5 \mathrm{hr}$ period. The oedema of the paw usually resolved within 2-3 days.

Twenty five Wistar rats $(150-200 \mathrm{~g})$ of both sexes (12 males and 13 females) were randomly assigned to 5 treatment groups of 5 rats each. $0.1 \mathrm{ml}$ of $1 \%(\mathrm{w} / \mathrm{v})$ carrageenin in $0.9 \%$ saline was injected into the subplantar surface of the right hind paw of each rat to induce inflammation. The pain threshold of the treated paw was measured in a Basile analgesy-meter $2 \mathrm{hr}$ after injection of the inflammatory agent. Thereafter, the rats were treated as follows: one group received $0.9 \%$ saline on weight basis (control); two groups received two dose levels of indomethacin, $10 \mathrm{mg} / \mathrm{kg}$ and $20 \mathrm{mg} / \mathrm{kg}$; the remaining two groups were given the extract at two dose levels, $1000 \mathrm{mg} / \mathrm{kg}$ and $2000 \mathrm{mg} / \mathrm{kg}$ respectively. The pain threshold was measured again at 1,2, 3, and $5 \mathrm{hr}$ after the treatment. Each group of rats was rotated through the entire five treatment groups, and the pain threshold measured in each rotation. Thus each rat served as a control as well as received the other four treatments. The hind paws used for induction of inflammation were alternated during the rotations, and the animals were rested for one week after every two rotations at 3-day interval.

\section{Data Analysis}

The mean pain threshold for each treated group was determined and compared with that obtained for each 
group before treatment. Percentage increase in pain threshold, $\mathrm{P} \%$, was derived, using the formula ${ }^{6} \mathrm{P} \%=$ $\{(\mathrm{Pt}-\mathrm{Po}) / \mathrm{Po}\} \times 100$ where $\mathrm{Pt}=$ pain threshold at time, $\mathrm{t}$, and $\mathrm{Po}=$ pain threshold at time zero (0). A graph of the percentage increase in pain threshold was plotted against time. The results are presented as mean+SEM. The presence of significant differences among group means was determined by one way ANOVA using (MegaStat, Excel) followed by the Newman-Keuls multiple comparison test with the level of significance at $\mathrm{p} \leq 0.05$.

\section{RESULTS}

In the hot-plate method, both the extract and indomethacin caused significant increase $(p<0.05)$ in the reaction time whilst normal saline caused no change. The percentage increase in the reaction time was dosedependent and differed significantly among the groups of mice $(p<0.05)$ receiving different dose levels of the extract and indomethacin (Table 1)

Table 1: Observations of percentage increase in reaction time in groups of mice given different dose levels of the extract and indomethacin.

\begin{tabular}{|c|c|c|}
\hline \multicolumn{2}{|c|}{$\begin{array}{l}\text { Paired Observations } \\
\text { (Means } \pm \text { SEM) }\end{array}$} & \multirow{2}{*}{$\begin{array}{c}\begin{array}{c}\text { p- } \\
\text { value }\end{array} \\
0.0051\end{array}$} \\
\hline $\begin{array}{l}\text { Extract } 400 \mathrm{mg} \\
(51.96 \pm 9.19)\end{array}$ & $\begin{array}{l}\text { Extract } 800 \mathrm{mg} \\
\quad(66.81 \pm 11.24)\end{array}$ & \\
\hline $\begin{array}{l}\text { Extract 400mg } \\
(51.96 \pm 9.19) \\
\end{array}$ & $\begin{array}{c}\text { : Indomethacin 5mg } \\
(77.80 \pm 8.03)\end{array}$ & 0.0011 \\
\hline $\begin{array}{l}\text { Extract } 400 \mathrm{mg} \\
(51.96 \pm 9.19)\end{array}$ & $\begin{array}{l}\text { : Indomethacin 10mg } \\
(90.04 \pm 9.59)\end{array}$ & 0.0007 \\
\hline $\begin{array}{l}\text { Extract } 800 \mathrm{mg} \\
(66.81 \pm 11.24)\end{array}$ & $\begin{array}{l}: \text { Indomethacin } 5 \mathrm{mg} \\
(77.80 \pm 8.03)\end{array}$ & 0.1198 \\
\hline $\begin{array}{l}\text { Extract } 800 \mathrm{mg} \\
(66.81 \pm 11.24)\end{array}$ & $\begin{array}{l}: \text { Indomethacin 10mg } \\
(90.04 \pm 9.59)\end{array}$ & 0.0182 \\
\hline $\begin{array}{l}\text { Indomethacin } 5 \mathrm{~m} \\
(77.80 \pm 8.03)\end{array}$ & $\begin{array}{l}\text { Indomethacin 10mg } \\
(90.04 \pm 9.59)\end{array}$ & 0.0045 \\
\hline
\end{tabular}

The percentage increase in the reaction time caused by the extract and indomethacin was detectable and peaked at $1 \mathrm{hr}$ and $2 \mathrm{hr}$ respectively but thereafter declined relatively to a nadir at $5 \mathrm{hr}$ after the administration of the extract or indomethacin (Figure 1)

Although the activity (percentage increase in reaction time)/time profile was identical for the extract and indomethacin, the rising phase of the curve was steeper for indomethacin than the extract but the converse was true during the declining phase. At $5 \mathrm{hr}$ after administration, indomethacin retained a significantly greater activity $(\mathrm{p}<0.05)$ than the extract.
At all the specified time intervals, the percentage increase in reaction time differed significantly $(p<0.05)$ between the extract and indomethacin at both dose levels, being greater for indomethacin except $1 \mathrm{hr}$ after the administration when there was no difference $(p=0.8756)$ in the effect between the extract and indomethacin at high dose levels, and at $2 \mathrm{hr}$ when the high dose extract $(800 \mathrm{mg} / \mathrm{kg})$ and low dose indomethacin $(5 \mathrm{mg} / \mathrm{kg})$ caused similar percentage increase in the reaction time $(\mathrm{p}=0.6654)$

At the peak of activity, $400 \mathrm{mg} / \mathrm{kg}$ and $800 \mathrm{mg} / \mathrm{kg}$ extract caused $74 \%$ and $95 \%$ increase in the reaction time respectively whilst $5 \mathrm{mg} / \mathrm{kg}$ and $10 \mathrm{mg} / \mathrm{kg}$ indomethacin gave $97 \%$ and $116 \%$ increment respectively. Time to peak activity was the same (2hr) for the extract and indomethacin at both dose levels.

In the paw pressure method, there was significant difference in mean pain threshold among groups of rats $(p<0.05)$ receiving different dose levels of the extract and indomethacin. The extract significantly $(\mathrm{p}<0.05)$ elevated pain threshold dose-dependently (Table 2 ) in the carrageenin pretreated rats, with the maximum elevation occurring $2 \mathrm{hr}$ after the administration (Fig 2). Indomethacin, like the extract, showed significant dose-dependent elevation $(\mathrm{p}<0.05)$ in pain threshold (Table 2). Compared to the extract, indomethacin caused a significantly greater elevation in pain threshold $(p<0.05)$ at both dose levels at all the specified time intervals except at $1 \mathrm{hr}$ after treatment when there was no significant difference $(p=0.7381)$ between the extract, $2000 \mathrm{mg} / \mathrm{kg}$, and indomethacin, $10 \mathrm{mg} / \mathrm{kg}$, which caused $44 \%$ and $48 \%$ elevation in pain threshold respectively.

Table 2: Observations of percentage increase in pain threshold in groups of rats given different dose levels of the extract and indomethacin.

\begin{tabular}{|c|c|}
\hline $\begin{array}{l}\text { Paired Observations } \\
\text { (Means } \pm \text { SEM) }\end{array}$ & p-value \\
\hline $\begin{aligned} \text { Extract } 400 \mathrm{mg} & : \text { Extract } 800 \mathrm{mg} \\
(51.96 \pm 9.19) & (66.81 \pm 11.24)\end{aligned}$ & 0.0051 \\
\hline $\begin{array}{cc}\text { Extract 400mg } & : \text { Indomethacin 5mg } \\
(51.96 \pm 9.19) & (77.80 \pm 8.03)\end{array}$ & 0.0011 \\
\hline $\begin{array}{cc}\text { Extract 400mg } & : \text { Indomethacin 10mg } \\
(51.96 \pm 9.19) & (90.04 \pm 9.59)\end{array}$ & 0.0007 \\
\hline $\begin{array}{cc}\text { Extract } 800 \mathrm{mg} & : \text { Indomethacin 5mg } \\
(66.81 \pm 11.24) & (77.80 \pm 8.03)\end{array}$ & 0.1198 \\
\hline $\begin{array}{cc}\text { Extract } 800 \mathrm{mg} & : \text { Indomethacin 10mg } \\
(66.81 \pm 11.24) & (90.04 \pm 9.59)\end{array}$ & 0.0182 \\
\hline $\begin{array}{l}\text { Indomethacin 5mg: } \text { Indomethacin 10mg } \\
(77.80 \pm 8.03)\end{array}$ & 0.0045 \\
\hline
\end{tabular}


As it was the case in the hot-plate method, the profile of the pain threshold/time curve was similar for the extract and indomethacin (Figure 2). Similarly, the rising phase of the curve was steeper for indomethacin than the extract whilst the converse was true during the declining phase. Indomethacin thus retained a significantly greater activity $(\mathrm{p}<0.05)$ than the extract $5 \mathrm{hr}$ after their administration. Time to peak activity was the same $(2 \mathrm{hr})$ for the extract and indomethacin.

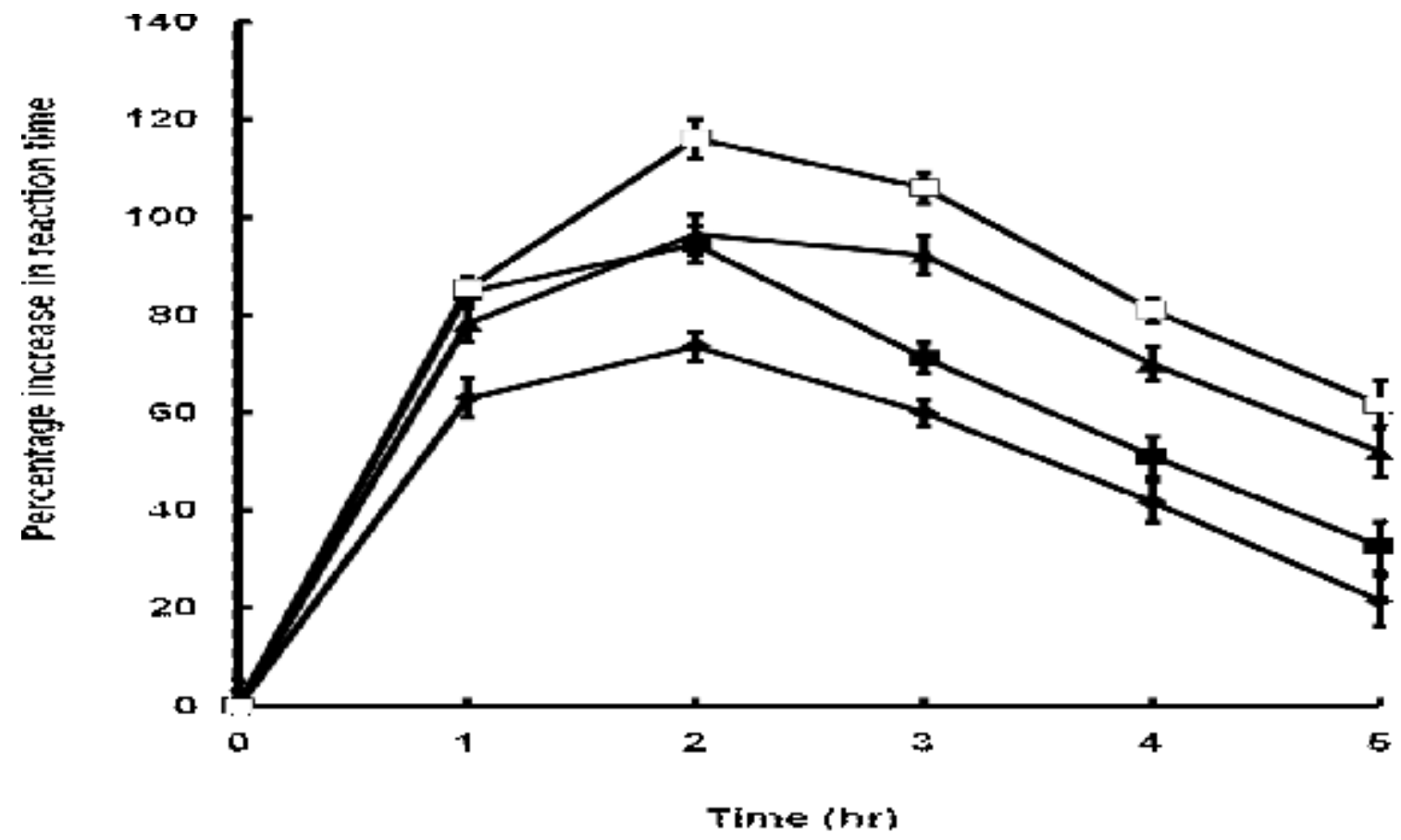

Figure 1: Percentage increase in reaction time in mice treated with extract $(\bullet-400 \mathrm{mg} / \mathrm{kg}$; and $\boldsymbol{\square}-\mathbf{\square}, 800 \mathrm{mg} / \mathrm{kg})$ and indomethacin $(\boldsymbol{\Delta}-\boldsymbol{\Lambda}, 5 \mathrm{mg} / \mathrm{kg}$; and $\square-\square, 10 \mathrm{mg} / \mathrm{kg})$. Each point represents the mean percentage increase in reaction time $\pm \mathrm{SEM}(\mathrm{n}=$ 25 mice).

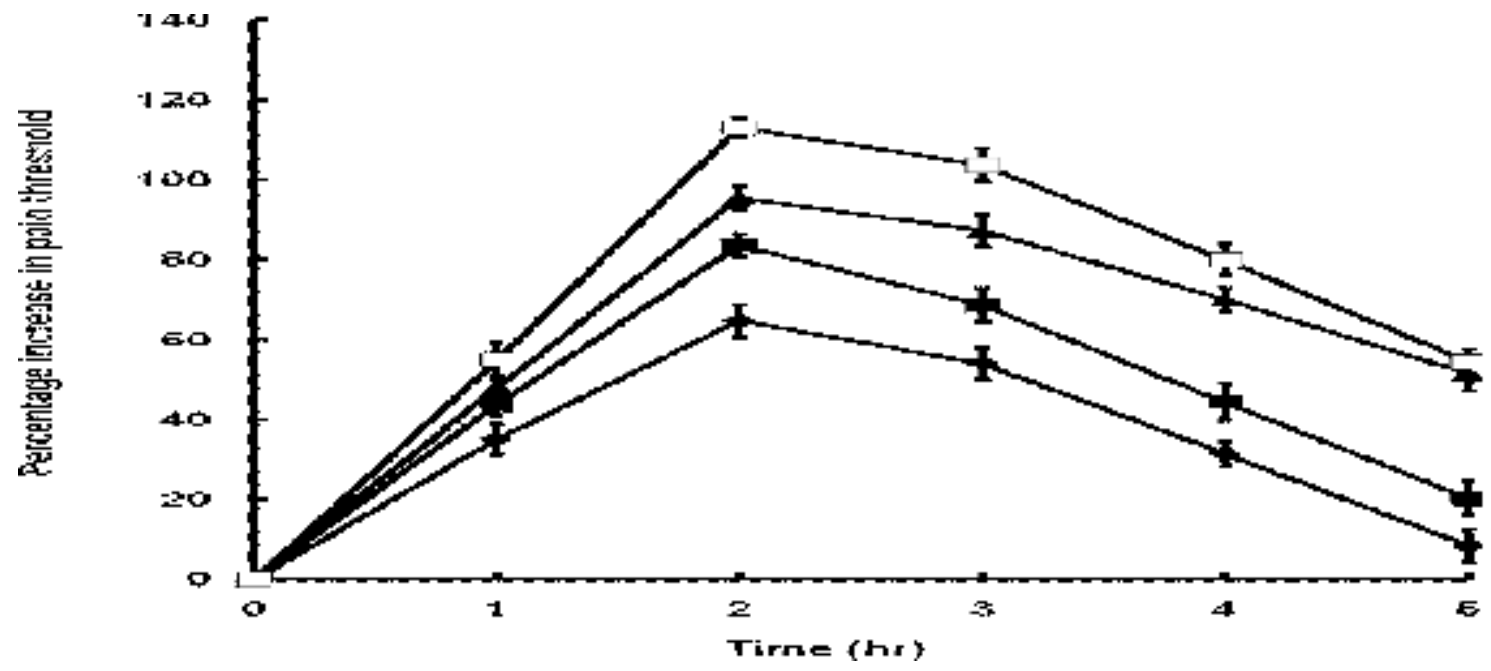

Figure 2: Percentage increase in pain threshold caused by extract $(\bullet-, 1000 \mathrm{mg} / \mathrm{kg}$; and $\mathbf{\square}-\mathbf{-} ; 2000 \mathrm{mg} / \mathrm{kg})$ and indomethacin $(\boldsymbol{\Lambda}-\boldsymbol{\Lambda}, 10 \mathrm{mg} / \mathrm{kg}$; and $\square-\square, 20 \mathrm{mg} / \mathrm{kg})$. Each point represents the mean percentage increase in pain threshold $\pm \mathrm{SEM}(\mathrm{n}=25 \mathrm{rats})$ 


\section{DISCUSSION}

In the two models used, the data show that the extract and indomethacin dose-dependently increased the pain threshold, and that the pain threshold/time profiles of indomethacin and the extract were similar (Figures 1 and 2).

Even though the profiles of the extract and indomethacin curves were similar, they differed in certain details. The rising phase of the indomethacin curve was steeper than that of the extract whilst the converse was true for the declining phase. Based on the fact that most drugs, including non-steroidal anti-inflammatory drugs (NSAIDs), must be present at the site of action for the maintenance of pharmacological response, the profile of the curves may be related to pharmacokinetic properties of the drugs. A very highly lipid-soluble drug, like indomethacin ${ }^{7}$, would be expected to be absorbed at a fast rate across the lipid bi-layer of the gastrointestinal tract (GIT) and build up quickly in plasma resulting in the steep rising phase of the curve. Also, indomethacin would distribute widely to most tissues and hence have large volume of distribution. It would, therefore, take a long time for indomethacin to be eliminated from the body, as reflected by the slow declining phase of the curve. The extract, on the other hand, is water-soluble and, as such, would be absorbed slowly across the lipid bi-layer of the GIT, build up slowly in plasma and distribute poorly to the tissues. The extract would thus exhibit slow entry into the circulation but rapid elimination from the body, giving rise to slow rising phase but fast declining phase respectively. As a corollary, the extract would have a shorter duration of action than indomethacin.

The increase in pain threshold indicates that the extract has analgesic property similar to indomethacin, a standard NSAID. Similar results obtained in rats, by using the paw pressure method, showed that $2.5 \mathrm{mg} / \mathrm{kg}$ indomethacin caused $48 \%$ increase in pain threshold; $200 \mathrm{mg} / \mathrm{kg}$ aspirin, $51 \% ; 25 \mathrm{mg} / \mathrm{kg}$ phenylbutazone, $52 \%$; and $9 \mathrm{mg} / \mathrm{kg}$ naproxen, $42 \%{ }^{8}$. The values presented in this study are congruent with those reported, though large doses of the extract were required to achieve comparable responses. The large doses of the extract used could be explained by the fact that the crude extract contains many compounds, among which the active principle responsible for analgesia occurs in minute quantity.

It is now well established that chemical mediators are responsible for the pain of inflammation. Inhibition of the synthesis and release of prostaglandin has been shown to be the major mechanism by which NSAIDs produce analgesia or reduce inflammation ${ }^{9}$. By this action, NSAIDs reduce the sensitization of afferent neurons by prostaglandins to the algesic actions of bradykinin and other pain provoking stimuli. As isolated and purified alkaloids of the root bark of Z. xanthoxyloids also have anti-prostaglandin synthetase activity ${ }^{2}$, it is most likely that the extract, like indomethacin and other NSAIDs, might induce analgesia by inhibiting the production and release of prostaglandins or blocking their receptors.

Following injury or injection of carrageenin, it takes $2 \mathrm{hr}$ for prostaglandin to be released ${ }^{11}$, a time period equivalent to the time lapse between the administrations of carrageenin and the extract or indomethacin. Thus the time lapse or dosing interval used in the pawpressure method was adequate to permit the release of prostaglandin. However, prostaglandin could not be implicated in the mediation of pain in the hot-plate method since responses of mice to thermal stimulus occurred within seconds, a time too short to permit the release of prostaglandin. This suggests that chemical mediators other than prostaglandin may be involved in the mediation of pain. Mediators of inflammation are released sequentially with histamine and serotonin being the first to be released within the first $30 \mathrm{~min}$, followed by kinins which are released about $1 \mathrm{hr}$ and prostaglandins, $2 \mathrm{hr}$ after induction of inflammation ${ }^{10}$. Because the analgesic property of the extract was also demonstrated in the hot-plate method, it could mean that the extract in addition to inhibiting prostaglandin may also interfere with the metabolism of other algesic agents or block the receptor sites of these agents.

\section{CONCLUSION}

Both the paw-pressure and hot-plate methods have been used to show that crude aqueous extract of the root bark of $Z$. xanthoxyloides has analgesic activity, underscoring its use in folklore medicine to relieve certain painful conditions. Since isolated and purified alkaloids of the root bark of $Z$. xanthoxyloides have anti-prostaglandin synthetase activity, it is possible that the analgesic activity of the extract may involve, mainly, inhibition of prostaglandin synthesis but interference of the metabolism of other algesic agents or blockade of their receptors could not be excluded. Further work is required to identify molecular mechanism(s) underlying the analgesic activity and, also, selectivity of COX I and II inhibitory activity of the extract.

\section{ACKNOWLEDGEMENT}

We wish to express our gratitude to Nana Asare and Ruth Addy for technical assistance and to Sophia Asare for typing the manuscript. 


\section{REFERENCE}

1. Ghana Herbal Pharmacopoeia, 1992; pp 56-58, Advent Press, Accra

2. Oriowo, M.A., Anti-inflammatory activity of Piperonyl-4-acrylic isobutyl amide, an extractive from Z.xanthoxyloides, Planta Medica, 1982; 44:54-6

3. Eddy N.B. and Liembach. D. Synthetic analgesics II: Dithienylbuttenyl and dithiennylbulyl-amines, J. Pharmacol. Exp. Ther, 1957; 107:385-393

4. Randall L. O. and Selitto J.A. A method for measurement of analgesic activity of inflamed tissue. Arch. Int. Pharmacodyn. Ther, 1957; 111:409-419

5. Vogel, A.L. A textbook of practical organic chemistry including qualitatitive organic analysis, fifth edition, 1989; pp 164-5 Longman Group.

6. Winter C. A., Risley E. A. and Nuss G. W., Carrageenin-induced oedema in the hind paw of rats as an anti-inflammatory drug. Proc. Soc. Biol.Expt. Med., 1962;111: 544-547.

7. Robert J. L. and Morrow J.D. Analgesic and antiinflammatory agents and drugs employed in the treatment of gout. In: Goodman and Gillman's. The Pharmacological Basis of Therapeutics, third edition, 1999; pp 705, ed. Hardman J.G., Limbird, L.E. and Gilman A.G., McGraw-Hill. New York.

8. Roszkowski A. P., Root H.W.H, Tomolonis A. J and Miller L.M. Anti-inflammatory and analgesic properties of $\alpha$-2-(6-methoxy-2-naphthyl) propionic acid (naproxen). J. Pharm. Exp. Ther. 1971; 179:114-123.

9. Ferreira S. H. and Vane J.R. New aspects of the mode of action of non-steroidal anti-inflammatory drugs. Ann. Rev. Pharmacol 1974; 14:57-71

10. DiRosa M., Girould J.P. and Willoughby, D.A. study of the mediators of the acute inflammatory esponse induced in rats in different sites by carrageenin and turpentine $J$. Path. (1971); 104: 15 - 29 